DOI: 10.32347/2412-9933.2021.45.6-12

UDC 005:8

\title{
Jalal Elbaruni
}

$\mathrm{PhD}$ Student at the Department of Project and Process Management, orcid.org/0000-0008-2242-2115

"KROK” University, Kyiv

\section{Bielova Olena Ihorivna}

$\mathrm{PhD}$ (in Economics), Associate professor, Associate professor at Marketing and Behavioral Economics department, orcid.org/ 0000-0001-9359-6947

«KROK» University, Kyiv

\section{Melenchuk Viktor Mikolayovich}

$\mathrm{PhD}$ (Eng.), Deputy Head of the Department of Repair and Operation of Automotive and Special Equipment, orcid.org/0000-0003-1236-6731

Military Academy, Odessa

\section{ANALYSIS AND PRIORITIZING RISK MINIMIZING TECHNIQUES OF IT PROJECTS}

\begin{abstract}
This article is devoted to the risk analysis of IT projects. The article defines the risks of IT projects, classifies the key risks of IT projects and identifies the main sources of risks of IT projects. The analysis of risks of IT projects at introduction of information management system in realization of projects of the company is also presented. The possibility of risks of IT projects during the implementation of the management information system in the implementation of the company's projects is analyzed. And also the ways of minimization of occurrence of risks of IT projects at introduction of information management system in realization of projects of the company are offered. Under ideal circumstances, in modern organizations, project implementation reduces risks to zero. At the same time, in modern realities, it remains necessary to take into account risks and manage them as part of the organization when implementing projects. Nevertheless, risk minimization is effective for the dynamic growth of an organization or institution when implementing projects. The current trends in information projects in today's competitive world are fundamental and necessary for any project-oriented organization to manage risks in information outsourcing projects in an ideally complex task. Thus, this article examines the main factors that lead to the emergence of risks, based on modern scientific sources from leading researchers in the field of project management, taking into account the peculiarities of developing an optimal risk management system in an organization when implementing projects, as well as the implementation of such a system under various scenarios of projects' implementation in organizations. A structure aimed at improving the risk management system in organizations during project implementation is also proposed. The study found that prioritization in the consideration of project risks, as well as risk factors, helps to correlate the risk of the project and the risk of the company itself. Prioritizing the response to risk factors and their strength of influence, considering the time, volume and quality of risks are of paramount importance for the dynamic growth of the organization and allow to conduct a matrix analysis of risks, and then propose ways to minimize risk.
\end{abstract}

Ключові слова: risk management; information risk sourcing; the project risk; company risk; analysis of risk prioritization; response to risk; a technique to minimize risk

\section{Formulation of the problem}

Every organization has a challenge in the information delivery and the acceptance of the information in the organization's effective running. There are so many risks in communication within an organization [1]. The probabilities of risk compare prioritization in solving the trouble with a higher percentage risk chronologically downward. Lower probability risk lowers the handle on the first identification. In actual practice, ideal assessing risk is complicated, hence balancing resources to mitigate the risk between high loss and lower probability in the management's exceptional occurrence [2]. The intangible risk on identifications of $100 \%$ risk probability but the organization due to lack of identification ability being the challenge. In the current modern unsafe world, the information processing ideal environment has numerous outstanding threats that have to jeopardize the significant needs of necessitating the ideal conditions of having the project and company risk espoused. It is considerable evidence of the dynamic increase in several companies 
that depend on the information's technological consideration and, therefore, the key reason and source for increasing competitive advantage. The efficiency market hypothesis that necessitates the organization or establishment needs information to hedge completion and being knocked out of the market. The permeance of the risk analysis is included in the possible consideration of adverse events that cause the natural processes of adverse events that cause malicious inadvertent on human activity. The essential ideal part of the risk analysis identifies the event's likelihood occurrence [3]. It ideal helps changes and enterprise environments in the inclusivity of new competitors, making ideal changes with government regulatory policies.

\section{The purpose and objectives of the publication}

The aim of the work is to develop and improve the mechanism of information risk management of an institution, work to find a mechanism to reduce risks of the project when there are risks in the project and company simultaneously, develop a concept of risk management for projects of small and medium-sized businesses, and according to modern project management methodologies and international standards.

\section{Presenting main material}

In every step of having the ideal necessity of managing the risk, the identification is the fundamental step. Creating a risk management strategy is essentially about formalizing the process and being able to allocate the resources more efficiently. Identifying the risks is the first step in this process, and one of the most important. It helps in enlightening the direction of the ideal risk management after understanding the problem.

In table 1 below, the various risks that should be expected from the implementation of the management information systems are identified. These risks are categorized as low, average and high in consideration of probabilities and extend of the risk. It plays an important role in determining which risks need to be given utmost attention even before starting the project implementation. The implementation has the ideal needs of having the effective management of the risk in the effectiveness reliability $[7 ; 8]$.

In the ideal scrutiny of the data in the table above, they have been a considerable understanding that risks management is a process [11]. The findings from Table 1 above are summarized in the matrix shown in table 2 below. The risks of most of these orders are in the high section, meaning that they need a lot of attention. No risk identified is categorized as low.

Form the interpretation of the information in the table, showing the presentation's ideal relevance that information summarizes. There are not low-risk areas in this particular scenario. Therefore, the project needs to get the highest level of attention it needs to ensure the risks are managed effectively [10].

Table 1 - Risks of the project (Implementation of MIS)

\begin{tabular}{|c|c|c|c|c|}
\hline No. & Risk name & Description & $\begin{array}{c}\text { Probabilit } \\
\text { y }(0-1)^{*}\end{array}$ & $\begin{array}{l}\text { Influence } \\
(0-1)^{*}\end{array}$ \\
\hline 1 & $\begin{array}{l}\text { Unclear responsibilities in } \\
\text { relation to the project }\end{array}$ & $\begin{array}{l}\text { This is likely to occur when the project is implemented } \\
\text { before the staff are informed of their various roles in the } \\
\text { process }\end{array}$ & 0.7 & 0.8 \\
\hline 2 & $\begin{array}{l}\text { Improper implementation of } \\
\text { the project deliverables }\end{array}$ & $\begin{array}{l}\text { This occurs when the deliverables are not implemented } \\
\text { as required. Therefore, it affects the effectiveness of the } \\
\text { resulting MIS }\end{array}$ & 0.5 & 0.7 \\
\hline 3 & $\begin{array}{lcr}\text { Lack of } & \text { a } & \text { detailed } \\
\text { specification } & \text { of } & \text { individual } \\
\text { action steps } & & \\
\end{array}$ & $\begin{array}{l}\text { When employees have no idea of what the steps are in } \\
\text { the project implementation, a lot of confusion tends to } \\
\text { occur }\end{array}$ & 0.5 & 0.8 \\
\hline 4 & $\begin{array}{l}\text { Unclear deliverables that do } \\
\text { not relate to business needs }\end{array}$ & $\begin{array}{l}\text { When the deliverables are not related to the business } \\
\text { needs, the resulting MIS will not trigger the expected } \\
\text { results due to incompatibility }\end{array}$ & 0.5 & 0.9 \\
\hline 5 & $\begin{array}{l}\text { An inexperienced project } \\
\text { manager }\end{array}$ & $\begin{array}{l}\text { The project manager should be highly skilled to offer } \\
\text { guidance to the team of employees responsible for the } \\
\text { implementation of the MIS }\end{array}$ & 0.1 & 0.9 \\
\hline 6 & $\begin{array}{l}\text { Project team members lack } \\
\text { the necessary skills }\end{array}$ & $\begin{array}{l}\text { When the team members lack the necessary skills, it } \\
\text { becomes impossible for them to carry out their roles as } \\
\text { needed }\end{array}$ & 0.4 & 0.8 \\
\hline 7 & $\begin{array}{l}\text { Lack of support from the top } \\
\text { management }\end{array}$ & $\begin{array}{l}\text { The top management should be willing to support the } \\
\text { employees by offering the necessary resources that will } \\
\text { facilitate effective MIS implementation }\end{array}$ & 0.6 & 0.8 \\
\hline 8 & $\begin{array}{l}\text { An inactive human resource } \\
\text { management department }\end{array}$ & $\begin{array}{l}\text { This department is a necessity as it encourages proper } \\
\text { behavior and outstanding performances from employees }\end{array}$ & 0.2 & 0.9 \\
\hline
\end{tabular}

* 0.1- very low (risk would not happen), 0.3- low, 0.5- average (probability of risk - 50X50), 0.7- high, 0.9- very high (risk almost certain would occur) 
Table 2 - Risk Probability Matrix for Scientific Projects

\begin{tabular}{|c||c||c||c|c|c|}
\hline \multicolumn{1}{|c|}{$\begin{array}{c}\text { PROBABI } \\
\text { LITY }\end{array}$} & 0.1 & 0.3 & 0.5 & 0.7 & 0.9 \\
\hline $0.8-1.0$ & & & & & \\
\hline $0.6-0.8$ & & & & $\mathbf{1}$ & \\
\hline $0.4-0.6$ & & & & $\mathbf{2 , 3 , 7}$ & $\mathbf{4}$ \\
\hline $0.2-0.4$ & & & & $\mathbf{6}$ & \\
\hline $0.0-0.2$ & & & & & $\mathbf{5 , 8}$ \\
\hline \multicolumn{4}{|l|}{ High risks area } \\
\hline \multicolumn{4}{|l|}{ Average risks area } \\
\hline \multicolumn{4}{|l|}{ Low risks area } \\
\hline
\end{tabular}

Hence, proper planning is needed before the project is implemented. It will ensure that project risks are effectively planned for so that they can be addressed before getting out of control. The risks 5, 6, and 8 are the average risks which do not pose a lot of threat. However, the rest must be addressed as quickly as possible.

Table 3 below features an analysis of the high risks of the project. These are the factors which must be addressed promptly to prevent any adverse outcomes of the project.

Table 3 above features an analysis of the high risks of the project. These are the factors which must be addressed promptly to prevent any adverse outcomes of the project. When the deliverables and actions taken to complete the project are not in line with the business needs, it will cause a crisis as the employees will be confused about which strategy to prioritize [4]. Also, support from top management is essential. When measures are taken to prevent the risks, the chances of better outcomes are increased. Also, if they have already occurred, it is important to immediately take action to salvage the situation before it is too late for positive outcomes.

Table 4 below lists the information risks for the company. Every company in considerable scrutiny has the risk that affects the company in several ways [9]. There are many risks which the company may experience as noted below.

Table 3 - High risks of project and how to do (Before/After)

\begin{tabular}{|c|c|c|c|c|}
\hline \multirow{2}{*}{ Risk Name } & \multicolumn{2}{|c|}{$\begin{array}{l}\text { Before the risk occurred } \\
\text { (Risk warning) }\end{array}$} & \multicolumn{2}{|c|}{$\begin{array}{l}\text { After the risk occurred } \\
\text { (Elimination of risk) }\end{array}$} \\
\hline & What to do? & $\begin{array}{l}\text { Who is } \\
\text { responsible? }\end{array}$ & What to do? & $\begin{array}{l}\text { Who is } \\
\text { responsible? }\end{array}$ \\
\hline $\begin{array}{l}\text { 1- Unclear } \\
\text { responsibilities in } \\
\text { relation to the } \\
\text { project }\end{array}$ & $\begin{array}{l}\text { - Regular meetings with } \\
\text { team. } \\
\text { - Proper communication } \\
\text { about their roles. } \\
\text { - Clarify roles by asking } \\
\text { for feedback }\end{array}$ & $\begin{array}{l}\text { - Project } \\
\text { manager }\end{array}$ & $\begin{array}{l}\text { - Re-plan of tasks. } \\
\text { - Clarify role by employing } \\
\text { the RACI matrix }\end{array}$ & $\begin{array}{l}- \text { Project } \\
\text { manager }\end{array}$ \\
\hline $\begin{array}{l}\text { 2- Improper } \\
\text { implementation } \\
\text { of the project } \\
\text { deliverables }\end{array}$ & $\begin{array}{l}\text { - Establish a clear project } \\
\text { scope. } \\
\text { - Be ready to keep } \\
\text { planning and making } \\
\text { changes }\end{array}$ & $\begin{array}{l}- \text { Team } \\
\text { Members }\end{array}$ & $\begin{array}{l}\text { - Introduce changes and } \\
\text { make plans immediately. } \\
\text { - Ensure the strategic goals } \\
\text { and objectives are properly } \\
\text { aligned with the } \\
\text { implementation }\end{array}$ & $\begin{array}{l}- \text { Project } \\
\text { Manager }\end{array}$ \\
\hline $\begin{array}{l}\text { 3- Lack of a } \\
\text { detailed } \\
\text { specification of } \\
\text { individual action } \\
\text { steps }\end{array}$ & $\begin{array}{l}\text { - Communicate the action } \\
\text { steps through personal } \\
\text { emails. } \\
\text { - Educate the team on the } \\
\text { project details }\end{array}$ & $\begin{array}{l}\text { - Project } \\
\text { Manager }\end{array}$ & $\begin{array}{l}\text { - Restart the project cycle by } \\
\text { educating the team. } \\
\text { - Specify steps that they are } \\
\text { required to take to make the } \\
\text { project a success }\end{array}$ & $\begin{array}{l}- \text { Project } \\
\text { Manager }\end{array}$ \\
\hline $\begin{array}{l}\text { 4- Unclear } \\
\text { deliverables that } \\
\text { do not relate to } \\
\text { business needs }\end{array}$ & $\begin{array}{l}\text { - Clearly define project } \\
\text { requirements. } \\
\text { - Map out a workable } \\
\text { communication path. } \\
\text { - Establish clear deadlines }\end{array}$ & $\begin{array}{l}\text { - Stakehol } \\
\text { ders }\end{array}$ & $\begin{array}{l}\text { - Develop deliverables that } \\
\text { are relevant to the business } \\
\text { needs. } \\
\text { - Ask the right questions such } \\
\text { as; why, what, who, and how. } \\
\text { - These answers should guide } \\
\text { the changes to be made }\end{array}$ & $\begin{array}{l}- \text { Project } \\
\text { Manager }\end{array}$ \\
\hline $\begin{array}{l}\text { 5- Lack of } \\
\text { support from the } \\
\text { top management }\end{array}$ & $\begin{array}{l}\text { - Involve all levels in the } \\
\text { project. } \\
\text { - Indicate the type of } \\
\text { support needed from the } \\
\text { top management }\end{array}$ & $\begin{array}{l}\text { - Project } \\
\text { Manager }\end{array}$ & $\begin{array}{l}\text { - Approach the management } \\
\text { with the project details and } \\
\text { ask for support where } \\
\text { necessary }\end{array}$ & $\begin{array}{l}- \text { Project } \\
\text { Manager }\end{array}$ \\
\hline
\end{tabular}


Table 4 - Information risks of the company

\begin{tabular}{|c|l|l|c|c|}
\hline No. & \multicolumn{1}{|c|}{ Risk name } & \multicolumn{1}{|c|}{ Description } & $\begin{array}{c}\text { Probability } \\
(0-1)\end{array}$ & $\begin{array}{c}\text { Influence } \\
(0-1)\end{array}$ \\
\hline 1 & Failed IT structure & IT structure that fails to support the project & 0.8 & 0.9 \\
\hline 2 & $\begin{array}{l}\text { Artificial intelligence } \\
\text { risks }\end{array}$ & $\begin{array}{l}\text { Artificial intelligence issues from technologies } \\
\text { that learn and self-improve }\end{array}$ & 0.4 & 0.5 \\
\hline 3 & Lost IT assets & Loss of IT assets such as mobile devices & 0.9 & 0.8 \\
\hline 4 & Ineffective IT audit & $\begin{array}{l}\text { Failure of the IT audit to identify problems such } \\
\text { as security vulnerability }\end{array}$ & 0.5 & 0.9 \\
\hline 5 & Service unavailability & IT services downtime & 0.4 & 0.5 \\
\hline 6 & Profit shortfall & $\begin{array}{l}\text { IT investments that fail to yield the return on } \\
\text { investment }\end{array}$ & 0.4 & 0.6 \\
\hline 7 & $\begin{array}{l}\text { Capacity management } \\
\text { failures }\end{array}$ & $\begin{array}{l}\text { Failures caused by problems such as network } \\
\text { overload }\end{array}$ & 0.7 & 0.9 \\
\hline 8 & Configuration risks & $\begin{array}{l}\text { Failures in change and configuration } \\
\text { management }\end{array}$ & 0.5 & 0.5 \\
\hline 9 & Legal risks & The potential of violating laws and regulations & 0.5 & 0.5 \\
\hline 10 & Partner failures & Violations of service level agreement by partners & 0.4 & 0.5 \\
\hline 11 & Permanent loss of data & Loss of data that cannot be restored & 0.7 & 0.8 \\
\hline 12 & $\begin{array}{l}\text { Inaccurate decision } \\
\text { automation }\end{array}$ & $\begin{array}{l}\text { Automation of wrong decisions due to poor } \\
\text { quality data }\end{array}$ & 0.8 & 0.9 \\
\hline 13 & Infrastructure failures & $\begin{array}{l}\text { Failures of basic factors such as networks and } \\
\text { power }\end{array}$ & 0.5 & 0.7 \\
\hline 14 & Physical security issues & The security of centers where hardware is stored & 0.4 & 0.5 \\
\hline 15 & Physical security issues & The security of centers where hardware is stored & 0.4 & 0.5 \\
\hline
\end{tabular}

The company risk is in several cases that after company risks include all areas of information technology, including the safety and legal aspects [12]. The probability of occurrence and resulting influence has been tabulated in the figure 5 Matrix below.

In table 5 above, the matrix features a summary of the nature of information risks that may be experienced by the company. There are no low risks. However, a few average risks have been identified [5]. The company also experiences quite several high risks since six factors are falling in this area. These represent the risks that must be prepared to prevent their occurrence.

Table 5 - Risk Probability Matrix for Scientific Projects (Risks of company)

\begin{tabular}{|c|c||c|c|c|c|}
\hline \multirow{2}{*}{$\begin{array}{c}\text { PROBA- } \\
\text { BILITY }\end{array}$} & \multicolumn{5}{|c|}{ INFLUENCE } \\
\cline { 3 - 6 } & 0.1 & 0.3 & 0.5 & 0.7 & 0.9 \\
\hline $0.8-1.0$ & & & & & $\mathbf{1 , 3}$ \\
\hline $0.6-0.8$ & & & & & $\mathbf{7 , 1 1 , 1 2}$ \\
\hline $0.4-0.6$ & & & $\mathbf{8 , 9 , 1 0 , 1 4}$ & $\mathbf{1 3}$ & $\mathbf{4}$ \\
\hline $0.2-0.4$ & & & $\mathbf{2 , 5 , 1 5}$ & $\mathbf{6}$ & \\
\hline $0.0-0.2$ & & & & & \\
\hline \multicolumn{7}{|c|}{ High risks area } \\
\hline \multicolumn{5}{|c|}{ Low risks area } \\
\hline
\end{tabular}

Table 6 below represents the possible high risks that may be experienced by the company. It is essential to consider these risks since the company will know where to focus much of its attention on.

Risk identification of the ideal needs of the evaluation strategies in the society of having the dynamic measurability of risk is necessary $[13 ; 14]$. The measures to be taken before the risk occurs, and if it takes place, have all been identified. Therefore, the company can prepare effectively for these risks before any projects can be undertaken.

Minimizing the information in considerable needs is necessitating the ideal needs of having an effective company and project necessity of the management of the organization's risk. Table 7 below features a summary of high risks that have been reduced upon a comparison between project and company risks. Since they are familiar, these are the high potential risks that should be looked out for minimization of information risk.

Several risk factors should be taken to consideration in the effective management of the organization in both project and company risk [6;15]. The risks include establishing clear roles and responsibilities, aligning the project strategy to the business goals, establishing a proper implementation process, and many others. When these are accounted for, the outcome of the project will be improved drastically. 


\section{Table 6-High risks of company and how to do (Before/After)}

\begin{tabular}{|c|c|c|c|c|}
\hline \multirow{2}{*}{ Risk Name } & \multicolumn{2}{|c|}{$\begin{array}{l}\text { Before the risk occurred } \\
\text { (Risk warning) }\end{array}$} & \multicolumn{2}{|c|}{$\begin{array}{l}\text { After the risk occurred } \\
\text { (Elimination of risk) }\end{array}$} \\
\hline & What to do? & $\begin{array}{l}\text { Who is } \\
\text { responsible? }\end{array}$ & What to do? & $\begin{array}{c}\text { Who is } \\
\text { responsible? }\end{array}$ \\
\hline $\begin{array}{l}\text { 1- Failed IT } \\
\text { structure }\end{array}$ & $\begin{array}{l}\text { - Establish the correct IT } \\
\text { structure for the current } \\
\text { project before starting }\end{array}$ & $\begin{array}{l}\text { IT } \\
\text { technician }\end{array}$ & $\begin{array}{l}\text { - Create a simple structure to } \\
\text { ensure ongoing operations as } \\
\text { the other permanent one is } \\
\text { getting repaired }\end{array}$ & IT technician \\
\hline 2- Lost IT assets & $\begin{array}{l}\text { - Educate the employees on } \\
\text { how to store and secure the } \\
\text { assets } \\
\text { - Prepare the right course of } \\
\text { action in case of a loss }\end{array}$ & $\begin{array}{l}\text { Authorized } \\
\text { personnel }\end{array}$ & $\begin{array}{l}\text { - Report the stolen asset to the } \\
\text { authorities for tracking } \\
\text { - Block all confidential files } \\
\text { that were present inside the } \\
\text { device }\end{array}$ & $\begin{array}{l}\text { Top } \\
\text { management }\end{array}$ \\
\hline $\begin{array}{l}\text { 3- Ineffective } \\
\text { IT audit }\end{array}$ & $\begin{array}{l}\text { - Follow an audit that has } \\
\text { been proven to be thorough }\end{array}$ & $\begin{array}{l}\text { IT } \\
\text { technician }\end{array}$ & $\begin{array}{l}\text { - Identify the gap in the audit } \\
\text { and immediately perform an } \\
\text { analysis }\end{array}$ & $\begin{array}{l}\text { Company } \\
\text { auditor }\end{array}$ \\
\hline $\begin{array}{l}\text { 4- Capacity } \\
\text { management } \\
\text { failures }\end{array}$ & $\begin{array}{l}\text { - Ensure the system will be } \\
\text { able to handle the number of } \\
\text { networks for the project } \\
\text { - Add more systems in case } \\
\text { the current one is not } \\
\text { sufficient }\end{array}$ & $\begin{array}{l}\text { IT } \\
\text { technician }\end{array}$ & $\begin{array}{l}\text { - Immediately remove some } \\
\text { networks from the system to } \\
\text { reduce the overload } \\
\text { - Establish another system to } \\
\text { handle the extra work }\end{array}$ & IT technician \\
\hline $\begin{array}{l}\text { 5- Permanent } \\
\text { loss of data }\end{array}$ & $\begin{array}{l}\text { - Educate the employees on } \\
\text { the importance of backing up } \\
\text { data to cloud } \\
\text { - Educate the employees on } \\
\text { how to secure data }\end{array}$ & $\begin{array}{l}\text { IT } \\
\text { technician }\end{array}$ & $\begin{array}{l}\text { - Check and correct the } \\
\text { erroneous data that is causing } \\
\text { inaccurate decision automation }\end{array}$ & IT technician \\
\hline $\begin{array}{l}\text { 6- Inaccurate } \\
\text { decision } \\
\text { automation }\end{array}$ & $\begin{array}{l}\text { - Ensure that the system has } \\
\text { the right commands to } \\
\text { ensure accurate decisions }\end{array}$ & $\begin{array}{l}\text { Top } \\
\text { management }\end{array}$ & $\begin{array}{l}\text { - Try to retrieve as much } \\
\text { information as is possible, } \\
\text { from the failed infrastructure }\end{array}$ & $\begin{array}{l}\text { Project Chief } \\
\text { engineer }\end{array}$ \\
\hline $\begin{array}{l}\text { 7- Infrastructure } \\
\text { failures }\end{array}$ & $\begin{array}{l}\text { - Always have backup in } \\
\text { place in case the current } \\
\text { infrastructure fails }\end{array}$ & $\begin{array}{l}\text { Company } \\
\text { manager }\end{array}$ & $\begin{array}{l}\text { - Establish a backup in a new } \\
\text { infrastructure }\end{array}$ & $\begin{array}{l}\text { Project Chief } \\
\text { engineer }\end{array}$ \\
\hline
\end{tabular}

Table 7 - Minimizing high risks by compared between information risks of project and company

\begin{tabular}{|c|c|c|c|}
\hline No. & Risk name & Risks of project & Risks of company \\
\hline 1 & $\begin{array}{l}\text { Poorly set expectations in } \\
\text { terms of deliverables and } \\
\text { having the right systems }\end{array}$ & $\begin{array}{l}\text { (4) } \\
\begin{array}{c}\text { Unclear deliverables that do not relate to } \\
\text { business needs }\end{array}\end{array}$ & $\begin{array}{l}\text { (5) } \\
\text { Permanent loss of data }\end{array}$ \\
\hline 2 & $\begin{array}{l}\text { Unclear roles and } \\
\text { responsibilities }\end{array}$ & $\begin{array}{l}\text { (1) } \\
\text { Unclear responsibilities in relation to the project }\end{array}$ & $\begin{array}{c}\text { (3) } \\
\text { Ineffective IT audit }\end{array}$ \\
\hline 3 & Poor data security & $\begin{array}{l}(5) \\
\text { Lack of support from the top management }\end{array}$ & $\begin{array}{c}\text { (6) } \\
\text { Inaccurate decision } \\
\text { automation } \\
\end{array}$ \\
\hline 4 & $\begin{array}{l}\text { Poor implementation } \\
\text { process }\end{array}$ & $\begin{array}{c}\text { Improper implementation of the project } \\
\text { deliverables }\end{array}$ & $\begin{array}{c}\text { (7) } \\
\text { Infrastructure failures }\end{array}$ \\
\hline 5 & Employee confusion & $\begin{array}{c}\text { (3) } \\
\text { Lack of a detailed specification of individual } \\
\text { action steps }\end{array}$ & $\begin{array}{l}\text { (1) } \\
\text { Failed IT structure }\end{array}$ \\
\hline 6 & $\begin{array}{l}\text { Improper } \\
\text { alignment }\end{array}$ & $\begin{array}{l}\text { (4) } \\
\begin{array}{c}\text { Unclear deliverables that do not relate to } \\
\text { business needs }\end{array}\end{array}$ & $\begin{array}{c}(3) \\
\text { Ineffective IT audit }\end{array}$ \\
\hline
\end{tabular}




\section{Conclusions}

Risk minimization is the ideal need to necessitate the necessity of having the practical needs of necessity. Everything is done in all possible situations to reduce the probabilities of risk towards the zero levels. The risk reservation views the unacceptable ideal at the individual level, organization, or society level. Risk management needs to have the significant needs of generating the necessity of risk assessment, risk mitigations on the strategic choice. The risk identification, evaluation and assessment, and risk mitigation with the contingency plan of necessitating needs of risk reduction. In every establishment, the organization personnel are risk-averse and need no risk at all. Hence minimization is the goal at all costs.

\section{References}

1. AL Qatawneh, A.S. (2016). The role of work teams' empowerment in crisis management: A case study of Jordanian electricity distribution company - Karak Governorate. International Business Research, 9(6), 10. URL: https://doi.org/10.5539/ibr.v9n6p10.

2. Strang, K., Korstanje, M. \& Vajjhala, N. (2018). Research, practices, and innovations in global risk and contingency management. IGI Global.

3. Boloș, M., Bradea, I. \& Delcea, C. (2019). Neutrosophic portfolios of financial assets. Minimizing the risk of Neutrosophic portfolios. Mathematics, 7 (11), 1046. https://doi.org/10.3390/math7111046.

4. Wieteska, G. (2020). Undefined. Operations and Supply Chain Management: An International Journal, 359-374. URL: https://doi.org/10.31387/oscm0430276.

5. Zabalawi, E.A., Bakhouche, A. \& El Chaar, R. (2021). Risk management. Advances in Business Strategy and Competitive Advantage, 206-225. URL: https://doi.org/10.4018/978-1-7998-4195-1.ch010.

6. Mahmud, S., Rahman, M.S., Hasan, M.M. \& Hossain, M.M. (2016). Minimizing the bullwhip effect in a single product multistage supply chain using a genetic algorithm. Uncertain Supply Chain Management, 137-146. URL: https://doi.org/10.5267/j.uscm.2015.11.001.

7. Information technologies. [Electronic resource]. URL: https://uk.wikipedia.org/wiki/\%D0\%86\%D0\%BD\%D1\%84\%D0\%BE\%D1\%80\%D0\%BC\%D0\%B0\%D1\%86\%D1\%96\%D0\%B 9\%D0\%BD\%D1\%96_\%D1\%82\%D0\%B5\%D1\%85\%D0\%BD\%D0\%BE\%D0\%BB\%D0\%BE\%D0\%B3\%D1\%96\%D1\%97.

8. Coburn, A. «People are both nonlinear and the most important components in creating software», Humans and Technology Technical Report, Oct.1999 (Russian translation by K. Maksimov, A. Maksimov URL: http://www.maxkir.com/sd/people_as_nonlinearRUS.htm) 25.

9. A Guide to the Project Management Body of Knowledge (PMBOK® Guide). (2017). Six Edition. USA. PMI, 574.

10. Yaroshenko, F.A., Bushuev, S.D. \& Tanaka, H. (2011.) Management of innovative projects and programs based on knowledge system P2M: Monograph. Kyiv, Ukraine, 263.

11. Mazur, I.I., Shapiro, V.D., Olderogge, N.G. Polkovnikov, A.V. (2010). Project management. Under general ed. I.I. Mazur and V.D. Shapiro. Moscow : Publishing house "Omega-L", 960.

12. Savina, O.Yu. (2017). Features of portfolios projects of science-based enterprises and their management peculiarities Management of Development of Complex Systems, 30, 62-74 [in Ukrainian].

13. Danchenko, O.B., Bielova, O.I. \& Safar, H.M. (2019). Ensuring effective quality management of trade enterprises through the use of the concept of TQM. Scientific notes of KROK University, 2 (54), 90-96. DOI: 10.31732/2663-2209-2019-5390-96.

14. Safar, H.M. \& Bielova O.I. (2020). Main components of Total Quality Management in projects of Libyan company "LISCO". Materials of the Fifth International Scientific-practical Conference "Project, Program, Portfolio. P3M Management", Odesa National Polytechnic University, Department of Project-based Learning in IT (04 - 05 December 2020), Book 1, Odessa, 98-101.

15. Bielova, O., Elbaruni, J.E. \& Safar, H.M. (2019). Benefits of integrating the Total Quality Management and Management Information System into Project Management. Collection of scientific works of ChSTU. Series: Economic Sciences. 2, 5-9.

16. Kolomytseva, O., Verenych, O., Danchenko, O., Bielova, O., Palonna, T. \& Pepchuk, S. (2020). Forming of integrated understanding of project terms: Faulk's algorithm as one of the formalized approaches. Entrepreneurship and Sustainability, 7(4), 3215-3225. URL: https://doi.org/10.9770/jesi.2020.7.4(42). 
Джалал Ельбаруні

Аспірант $\mathrm{PhD}$ кафедри управління проєктами та процесами, orcid.org/0000-0008-2242-2115

Університет «КРОК», Київ

Бєлова Олена Ігорівна

Кандидат економічних наук, доцент, доцент кафедри маркетингу і поведінкової економіки, orcid.org/0000-0001-9359-6947

Університет «КРОК», Київ

Меленчук Віктор Миколайович

Кандидат технічних наук, заступник начальника кафедри ремонту та експлуатації автомобільної та спеціальної техніки, orcid.org/ 0000-0003-1236-6731

Військова академія, Одеса

\section{АНАЛІЗ І ПРІОРИТЕЗАЦІЯ МЕТОДІВ МІНІМІЗАЦІЇ РИЗИКІВ ІТ-ПРОЄКТІВ}

Анотація. Стаття присвячена аналізу ризиків IT-проєктів. У статті дано визначення ризиків IT-проєктів, проведена класифікачія ключових ризиків IT-проєктів, а також визначено основні джерела ризиків IT-проєктів. Проаналізовано можливість виникнення ризиків IT-проєктів при впровадженні інформачійної системи управління 6 реалізацію проєктів компанії. Також запропоновано шиляхи мінімізації виникнення ризиків ІТ-проєктів при впровадженні інформаційної системи управління в реалізацію проєктів компанії. За ідеальних обставин в сучасних організаціях при реалізачії проєктів ризики зводяться до нуля. У той же час в сучасних реаліях залишається необхідність враховувати ризики і управляти ними як частиною організації при реалізації проєктів. Проте мінімізація ризику ефективна для динамічного зростання організаиії або установи при реалізації проєктів. Поточні тенденції в інформачійних проєктах в сучасному конкурентному світі є фундаментальними і необхідними для будь-якої проєктно-орієнтованої організації, щоб управління ризиками при інформачійному аутсорсингу в проєктах було ідеально складеним завданням. Отже, в пропонованій статті розглядаються основні фактори, які призводять до виникнення ризиків, трунтуючись на сучасних наукових джерелах від провідних дослідників у сфері управління проєктами, враховуючи особливості розробки оптимальної системи управління ризиками в організачії при реалізачії проєктів, а також впровадження подібної системи за різними сценаріями реалізації проєктів в організаціях. Також запропонована структура, спрямована на роботу з поліпшення системи управління ризиками в організаціях при реалізації проєктів. У роботі встановлено, щзо розстановка пріоритетів в обліку ризиків проєктів, а також фактори ризиків допомагає співвіднести ризик проєкту $i$ ризик самої компанії. Пріоритезація реагування на фактори ризику $і$ їх силу впливу, розгляд витрат часу, обсягу $і$ якості ризиків мають периорядне значення для динамічного зростання організації та дають змогу провести матричний аналіз ризиків, а потім запропонувати иляхи мінімізації ризику.

Ключові слова: управління ризиками; інформаційне джерело ризику; ризик проскту; ризик компанії; аналіз пріоритетності ризиків; реакція на ризик; методика мінімізації ризику

\section{Link to the article}

APA Elbaruni, J. \& Bielova, O. \& Melenchuk, V. (2021). Analysis and prioritizing risk minimizing techniques of IT projects. Management of Development of Complex Systems, 45, 6-12; dx.doi.org\10.32347/2412-9933.2021.45.6-12.

ДСТУ Джалал Ельбаруні, Бєлова О. І., Меленчук В. М. Аналіз і пріоритезація методів мінімізації ризиків IT-проєктів. Управління розвитком складних систем. Київ, 2021. № 45. С. 6 - 12; dx.doi.orgl10.32347/2412-9933.2021.45.6-12. 